\title{
Mark Kuhlberg \\ One Hundred Rings and Counting: Forestry Education and Forestry in Toronto and Canada, 1907-2007
}

Toronto: University of Toronto Press, 2009. 334 pp.

\section{Bill Parenteau}

University of New Brunswick

In One Hundred Rings and Counting: Forestry Education and Forestry in Toronto and Canada, 1907-2007 Mark Kuhlberg has presented a lively, well written and sometimes compelling institutional history of the University of Toronto Faculty of Forestry. It breaks new ground in its richly detailed examination of forestry education in Canada and the challenges faced by professional foresters in the first half of the twentieth century. One Hundred Rings and Counting is also a valuable contribution to the history of universities and higher education in Canada for its intense focus on the relationship between middle level management (deans) and upper management (presidents and governing bodies) at the University of Toronto. Both the Faculty of Forestry and Kuhlberg deserve credit for publishing a commissioned history that is less celebratory than analytical. While there are some criticisms to be leveled against the author in terms of insufficient attention to context and static and dismissive views of the provincial state and environmental movement, it is a monograph that deserves praise and a wide readership.

Above all else, One Hundred Rings and Counting is a "Dean's eye view" of the evolution of forestry education at the University of Toronto. The chapters are organized, for the most part, around the tenures of individual deans, and the central focus is on how the men holding the office navigated their way through university politics and negotiated relationships between the faculty and government and industry. Despite being the first in Canada, the Faculty of Forestry at the University of Toronto consistently struggled along as a poor cousin of other faculties within the institution. The most compelling part of Kuhlberg's work is his penetrating analysis of the struggles 
of individual deans to maneuver the University of Toronto administration into addressing the chronic space and resource deficiencies experienced by the faculty. For all of the deans of forestry in its first hundred years of existence, the job was made more difficult by an administration that consistently reminded them - mostly by withholding resources but sometimes by painfully blunt statements - that the needs of the faculty were insignificant in the larger scheme of addressing institutional priorities. Those holding or wanting to hold university deanships would benefit from reading One Hundred Rings and Counting as Kuhlberg doles out balanced and convincing assessments of the strategies of the each of the deans of forestry. Although he leaned very heavily on the documentary record left by deans, Kuhlberg does a very good job in pointing out where individual deans failed to see opportunities and made political errors and strategic mistakes. His examination of the sometime Byzantine world of faculty-university politics suggests that even in the best of times, including the expansionary period in the 1950s and 1960s, the pie at Canadian universities is never quite big enough and some are left wanting.

A second major theme in One Hundred Years and Counting is the celebration of the achievements of University of Toronto forestry graduates. Indeed, a section of each chapter is devoted to the achievements of those who went on to have noteworthy careers in forestry and other professions. On one hand, the focus on graduate achievements takes away from the overall analytical thrust of the monograph. On the other hand, it is certainly defensible in a commissioned history and adds value to the work in the sense that it allows for an understanding of changes in the student body and the job market for foresters over time. Moreover, there are some compelling stories that are uncovered. Most notably among them is the poignant recounting of the relationship between Bernard Fernow, the first dean, his wife Olive, and "their boys" who fought in the First World War. At the same time, Fernow was defending himself against those who cast aspersions on his Prussian heritage. Kuhlberg thus provides a brief but valuable account on how the Great War was experienced in the university setting.

The third major theme in One Hundred Years and Counting is the relationship between the faculty, and the forestry profession, in general with the provincial government and industry. In this regard, the title of the book is a bit misleading. The monograph is predominantly about forestry education in Toronto, and forestry and forestry education in Canada are lightly treated. While it would be too much to expect equal treatment for these topics, the interpretation of Ontario provincial forest policy comes off as static. That is, Kuhlberg continually criticizes and dismisses Ontario policy as backward and patronage ridden throughout the first half of the twentieth century. Context is lacking in these assertions; he never explains how other provinces had made progress over and above Ontario and in some areas the province appears to have been progressive. The introduction of air surveillance for fire fighting shortly after the First World War, to cite one example, seems quite advanced compared to most jurisdictions in North America. Kuhlberg is also critical of the Ontario government for not supporting the silviculture programs of pulp and paper companies. Again, the context of state formation is missing. As he points out, Ontario 
derived thirty percent of its provincial revenue from the Crown forest in 1900, a time when the state engaged in almost no direct aid to industry. As in other provinces, the state in Ontario was reconstructed over the course of the next half-century to accommodate the rise of large-scale, multi-national capital in the natural resource sector. With regard to the forest sector this process involved, most significantly, the transformation of the Crown lands department from a revenue generating apparatus for the state to a service agency for industry. In criticizing the lack of support for industry initiated forestry schemes, Kuhlberg superimposes a post-Second World War state ideology on a First World War era provincial government. Lastly, the interpretation of the environmental movement in One Hundred Years and Counting is pejorative and unconvincing.

Setting minor criticisms aside, One Hundred Years and Counting is a very good book. As the author notes, it "is not a simple story to tell," considering the University of Toronto Faculty of Forestry struggled for most of its history, as a result of forces both internal and external, and in the end (1993) was forced to close down its undergraduate program. Mark Kuhlberg deserves credit for both telling the story well and using the experience of the faculty as an opportunity to provide a first rate analysis of the inner working of a major university in Canada over the course of a century. 